\title{
A Critical Analysis of Gold Prospecting Methods
}

\author{
Barry Mamadou Saliou, Xinwu Huang \\ China University of Geosciences, Beijing, China \\ Email: barryms33@yahoo.fr
}

How to cite this paper: Saliou, B.M. and Huang, X.W (2020) A Critical Analysis of Gold Prospecting Methods. International Journal of Geosciences, 11, 15-24. https://doi.org/10.4236/ijg.2020.112002

Received: December 29, 2019

Accepted: February 2, 2020

Published: February 5, 2020

Copyright (C) 2020 by author(s) and Scientific Research Publishing Inc. This work is licensed under the Creative Commons Attribution International License (CC BY 4.0).

http://creativecommons.org/licenses/by/4.0/

(c) (i) Open Access

\begin{abstract}
Exploration and prospecting for mineral resources deposits are perceived to not be an easy process due to big deposits being discovered in early times. Numerous gold prospecting methods have been used in gold prospecting. The aim of this research is to critically analyze both traditional and modern gold prospecting methods that are being used in gold exploration. The research objective is to critically evaluate the numerous studies that focus on gold prospecting methods in an effort to provide an effective analysis of gold prospecting methods. In doing so, the study has used a qualitative method to review the existing literature. The study reviews academic journals and articles, books, and periodicals which were published between 2010 and 2019 . This study has achieved to critically analyze both traditional and modern gold prospecting methods. The study finds out that the traditional gold prospecting methods include gold panning and dry washing. Additionally, the current gold prospecting methods include biological prospecting, geochemical prospecting and geophysical prospecting methods.
\end{abstract}

\section{Keywords}

Gold Prospecting, Geochemical Prospecting, Gold Panning, Biological Prospecting, Geophysical Prospecting

\section{Introduction}

Since the earliest settlement need for mineral sources such as copper for utensils, lead for bullets, and iron for guns and tools has stimulated an exploration for sources of these mineral resources. Hence, prospectors have largely contributed to the development of the world's mineral resources. The lure of silver and gold has offered the impulse for much of development of mineral resources in the western countries between 1850 and 1910 [1]. Over the years, prospectors have performed successful ventures in an effort to fulfill the world's expanding industrial demands for gold and other mineral resources. Even United States barred 
deserts and uninhabited rugged mountains have been prospected even though on an exploration scale. It is evident that in the United States approximately one billion tons of underground and surface material is mined on an annual basis to recover around 500 million tons of metallic ores such as copper and iron [1].

According to Crowson [2], there are elements such as area selection, motivated and skilled people, along with effective exploration models and technology which have led to the success of these minerals exploration. Fletcher [3] argues that one of the most useful minerals mined in the world is gold. In gold exploration, there are numerous gold prospecting methods ranging from traditional and current gold prospecting methods. Some of the traditional gold prospecting methods that are evaluated in this analysis include gold panning and dry washers.

The modern gold prospecting methods that are analyzed include biological, geophysical, geochemical prospecting methods. However, these modern gold prospecting methods have numerous techniques. For instance, there are numerous geophysical prospecting methods such as geo-electric, seismic, radiometric, gravimetric, and magnetic methods which are analyzed in this study.

This journal critically analyzes the gold prospecting methods and the traditional and current gold prospecting techniques which have been widely utilized and ascertained to be successful in present gold prospecting. This study emphasizes that there are no two gold prospecting methods which are the same and gold prospectors and mining corporation have their own preferred or different techniques for gold prospecting.

\section{Materials and Methods}

In looking at the gold prospecting methods, the methodology that is used is the qualitative research method. Quick and Hall [4] indicates that qualitative method is centered on capturing what individuals do or sat as a product of their interpretation of the complex world. This means that qualitative method emphasizes on understanding the perspectives of the respondents' proceedings. Basically, the qualitative method investigates why certain activities occur the way they do and not how they occur the way they do. Hence, qualitative method is a non-numeric approach since it does not contain quantifiable information or data. In using qualitative research method, it assists in creating research strategies. According to Saunders et al. [5], qualitative research method can involve document analysis, in-depth interviews, short responses, and online questionnaires. Through using this research method, it provides unexpected information.

The research approach that is used in critically analyzing gold prospecting methods is explanatory research approach. This research approach attempts to elucidate moreover establish how and why there is a relationship amid two elements of a phenomenon. This is achieved through attempting to clarify why a specific problem or objects occurs in the manner that they do. For instance, in using explanatory research approach it assists in looking at the various gold prospecting methods and which is the most appropriate method. The explanatory research approach emphasizes the cause-effect relationship in the pheno- 
menon. According to [6], this research approach relates the phenomenon to broad economic, social and political processes which can be employed to predict the results. The need to use explanatory approach is due to increasing the understanding of the researcher on the specific subject. Even though explanatory approach does not offer conclusive outcomes due to lack of statistical strength, it is evident that it assists in determining how and why specific phenomenon occur. Additionally, the explanatory approach provides the flexibility of sources due to using secondary sources like academic journals and published literature.

This study in collecting data used secondary sources. Hence, existing literature was reviewed in an effort to accurately provide information relating to gold prospecting methods. It should be noted that secondary sources were used to review existing literature in an effort to obtain theoretical information regarding the issue under investigation. Some of the secondary sources used include academic journals and articles, books, corporate reports, periodicals, and internal memos. The reviewed literature was published between 2010 and 2019 to ensure that the reviewed literature was up to date.

\section{Results}

\subsection{Gold Panning}

One of the gold prospecting methods that are used by prospectors is gold panning. It should be realized that gold panning is perceived to be the most inexpensive and common technique for gold prospecting. Gold panning has been argued to be the most widely used and the oldest gold prospecting method. Gold pans are available in numerous sizes and shapes. However, the standard American gold pan at the top is perceived to be around 15 inches to 18 inches in diameter, while in depth it is two to two and half inches with the sides of the gold pan sloping 30 to 45 degrees. Additionally, the gold pans are built of plastic or metal. Figure 1 shows metal gold pans.

Gold pans are applied in cleaning gold-bearing concentrates, gold prospecting, as well as hand working of isolated and rich deposits even though rarely. Hence, at the bottom of the gold pans heavy minerals are concentrated while at the top is where the lighter materials are removed to ensure that the basic operation of gold panning is simple. However, skills and experience are required to
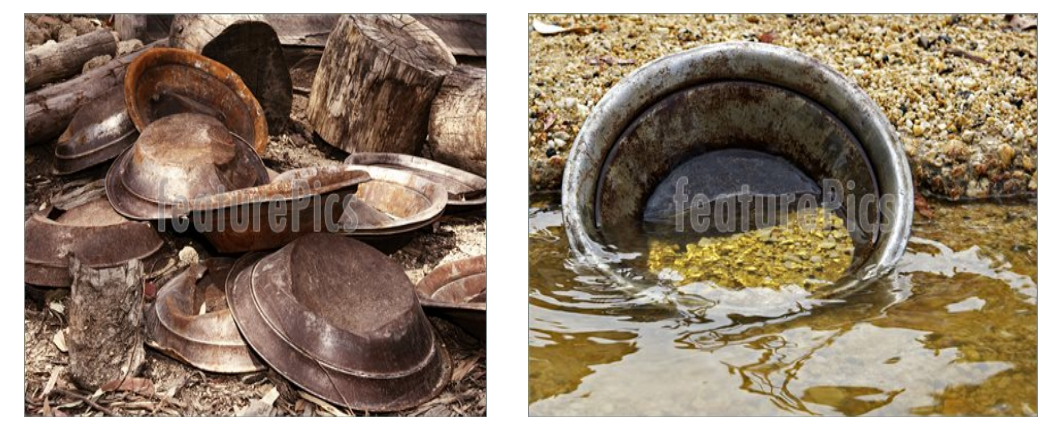

Figure 1. Gold pans. 
process huge amounts of materials which attaining maximum recovery. To appropriately learn the basic gold panning there is need to learn from a skilled and experienced gold panner.

Gold panning has been widely utilized as the primary prospecting method in the early times. Nonetheless, it is evident that gold panning is exceedingly limited since it only recovers coarse gold while fine grained gold is normally washed away with the pebbles. This is due to most experienced panners can only process small amounts of gravel. In the modern world, gold panning has been used for cleaning concentrate and prospecting. The benefits of gold panning such as portability, immediate availability, and low price make it a vital instrument for prospectors. Gold panning is still being utilized for gathering geologic information. Nonetheless, in the modern world it is being supported by electrostatic separation, electromagnetic, and mechanical techniques along with instrumental mineralogical evaluation and microscopic examination.

\subsection{Biological Prospecting}

Biological prospecting is another method that has been used in gold prospecting. Bacteria, humus, and plants have been utilized successfully as assistances in mineral prospecting. These bacteria and plants have been argued that under specific circumstances they might help prospectors in locating buried metals/mineral deposits [7]. In biological prospecting, there are numerous factors which are involved. Eun Jung [8] argues that this method is a valuable aide to traditional prospecting techniques. This is due to numerous plants through their roots' absorptive ability and extensive root systems efficiently absorb numerous elements which might be within their reach and might distribute these elements to leaves, stems moreover branches that can be evaluated chemically. Plants under perfect circumstances samples underlying rocks and soil in their root zone. There are numerous advantages that prospectors have in having the capability of sampling plants.

One technique of biological prospecting is biogeochemical prospecting. According to Dunn [9], biogeochemical prospecting is established on the basis that trees and other plants might uptake some elements from primary substrate while accumulating then in their foliage and roots. This is supported by [10] who indicate that plants that collect increased metal concentrations from the substrate might be utilized as indicators plants for biogeochemical prospecting. Numerous studies illustrate that biogeochemical exploration is a successful and effective mineral prospecting technique [8] [11] [12]. This is facilitated by the fact that indicator species that accrue metals in percentage to its quantity in biogeochemical composition and in soil replicates the sub surface's geochemical signature.

Gold prospectors through using biogeochemical prospecting are capable of obtaining information regarding mineral deposits which happen at substantial depths. Nonetheless, there are issues in interpreting the obtained information which might make this prospecting technique to be impractical under several field conditions [13]. This is evident in that some plants or bacteria due to their 
genetic makeup might concentrate elements selectively in their leaves, stems or roots in higher concentrations as compared in the underlying rocks and soil. It is vital for prospectors where possible to analyze rock and soil samples prior to come to the conclusion that the geo-botanical anomaly suggests the presence of gold ores in the region.

As well, it is evident that forest humus has been utilized to located mineralized rocks successfully specifically in instances that the mineral resources are hidden by soil. This is due to the elements being concentrated and immobilized in the humus layer as leaves or twigs and fall to the ground surface and decay. According to Mehrabi et al. [14], forest humus chemical analysis in Iran provides the results that it has led to delineated zones of gold which was perceived to be more accurate as compared to findings from the underlying soil.

\subsection{Dry Washers}

Dry washing is a gold prospecting method that uses a dry washer. Basically, a dry washer is perceived to be a waterless and short sluice. The dry washer uses pulsations of air via a porous medium to isolate gold from sand. In a dry washer, screened gravel goes down through inclined riffle boxes with cross riffles. The box's bottom comprises of canvas or some other material/fabric [15]. Underneath the riffle boxes there are bellows that blow in strong and short puffs through the fabric/canvas. This process provides a classifying action and combined shaking to the material. Hence, the gold sinks downwards to the canvas while being held by the riffles. On the other hand, the waste goes over the riffles and out of the dry washer.

Dry washer is made up of a frame that a heavy and well-braced screen is enclosed with burlap overlain with fly screen and/or window while being enclosed with fine linen. Figure 2 shows a typical dry washer. A power dry washer is

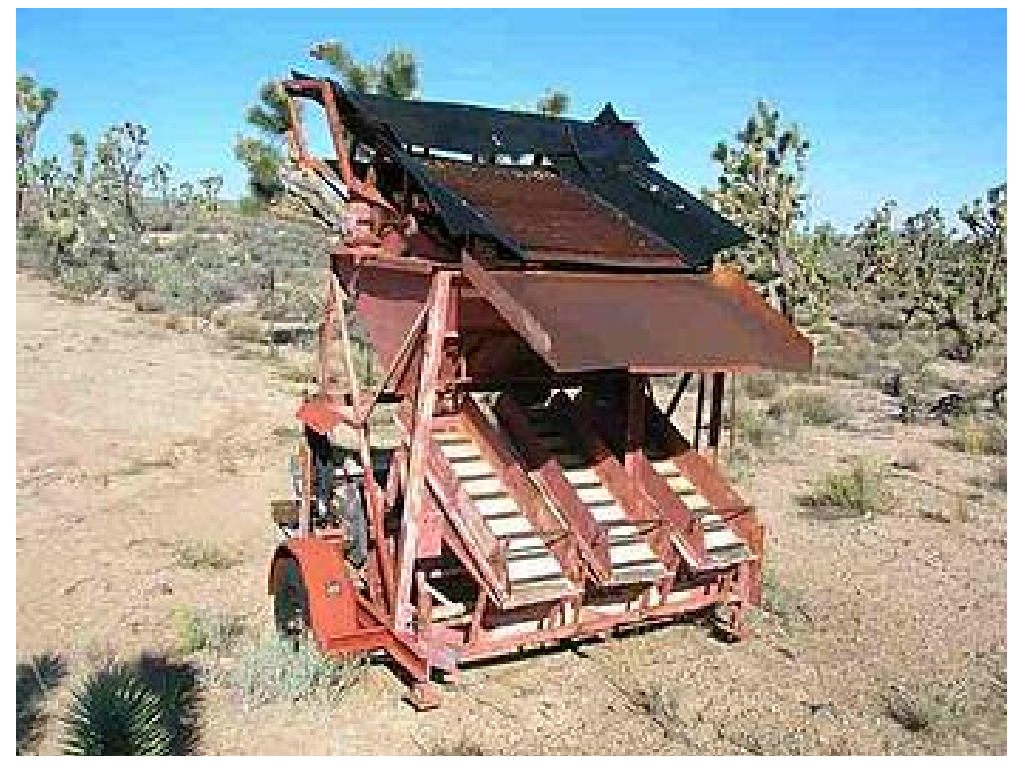

Figure 2. Dry washers. 
estimated washer is estimated to process around 21 cubic feet of screened material on an hour basis [16]. On the other hand, hand-powered dry washers which are operated by two individuals are estimated to process approximately one or more cubic yards per eight hours. Nonetheless, this depends on the handled material size. The dry washer prospecting technique affects the gold or needs to be entirely disintegrated and dry. If the gold ore is considerably damp then prior to treatment it needs to be dried. Sun can be used to dry the gold ore for small-scale work. The dry gold ore in operations is put into the dry washer's vibrating screen where the gold fines drop through the box riffles while the oversized gold falls off the dry washer's edge. The screen and bellows of the dry washer are powered by small engines or operated by hand. The dry washer's bellows are operated at approximately 250 pulsations per minute with around 3 inches stroke [17]. However, there can be variation of these figures depending on the gold fineness and processed material's coarseness.

\subsection{Geochemical Prospecting}

Another technique used in gold prospecting is geochemical prospecting. This method is established on orderly measurement of chemical aspects of water, stream sediments, glacial debris, soil and rocks as depicted in Figure 3. In this method, the most commonly chemical property calculated is the content of a main trace element. The zones in rocks and soil of anomalous or comparatively high concentrations of specific elements might lead prospectors to the elements in soils and rocks which comprise a geochemical anomaly [18]. In geochemical prospecting, the actual amount of the chief element in the samples might be very small while constituting an anomaly in cases where the concentration of the

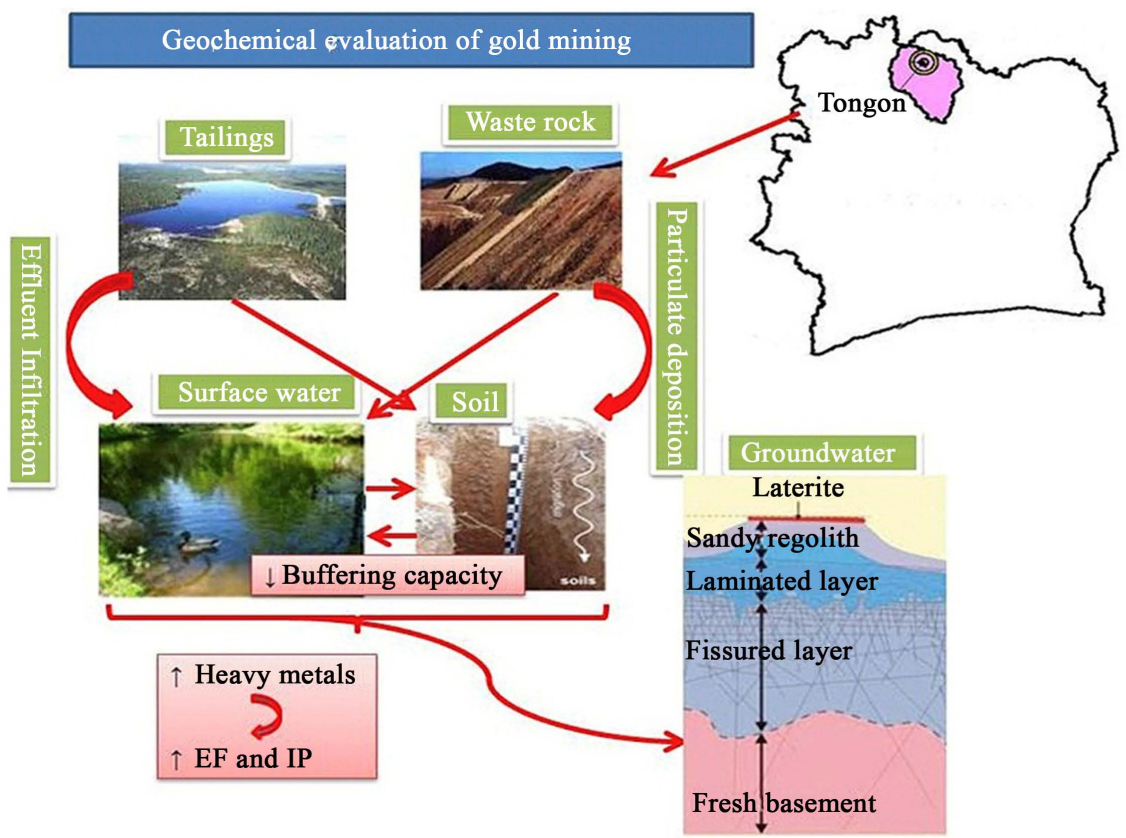

Figure 3. Geochemical evaluation of gold mining. 
sample is relatively high to the surrounding region's concentration. For instance, where most rock samples are established to comprise around $0.00002 \%$ gold where a few of the samples comprise as much as $0.0002 \%$, then it indicates that the few high concentrations are perceived to be geochemical anomalies. Hence, when the analytical results are plotted on a map they might illustrate zones that need further exploration.

Geochemical anomalies are categorized as secondary anomalies or primary anomalies. This means that the primary anomalies are due to outward elements' dispersion by mineral-forming solutions. In primary anomalies the metals' high concentrations surround the deposit. This implies that vertical or lateral dispersion of metals along faults or fractures might lead to a "halo" surrounding the deposit. According to [3], halos are particular helpful in prospecting since they might be hundreds of times greater than the surrounding deposit which makes them easier to locate.

On the other hand, secondary anomalies are perceived to result from elements' dispersion through weathering. Gold being a primary mineral is resistant to chemical weathering which indicates that the streams transport gold as fragmental material. Other primary minerals might be dissolved and carried away in solutions or locally redeposited in surface and ground waters [1]. In solution, some elements are taken up by trees/plants which indicate that they might be concentrated in these plants' tissues. It should be noted that the metal anomalous amounts distribution in soil has been established to closely match with the metals' concentration in the underlying rock. Most weathering products in the drainage basin enter the rivers along with the streams which flow across it. Hence, the weathered products transpire as chemicals in the solution in the water of the rivers along with their sediments. These weathered products in the solution can be tested or sampled where the samples' composition might reflect the rocks' chemical nature in the drainage basin. This implies the presence of gold ore might be evaluated through sampling sediment and water from every successive tributary along with through evaluating the samples for metals' anomalous amounts [19]. Through using this procedure, it narrows for the exploration of gold ore deposits to the most promising regions.

In geochemical prospecting, there are some analytical methods which are employed and need to sensitive in an effort to evaluate the small concentration differences [20]. There are numerous analytical methods which have been invented to assist in geochemical prospecting. These analytical techniques vary from simple procedure to complex procedures. Simple procedures can be performed in the field while complex ones need well-equipped laboratories. One of such analytical methods is the wet chemical method which is normally limited to quick colorimetric procedure which needs a minimum of materials and equipment.

\subsection{Geophysical Prospecting}

Another method that has been used in gold prospecting is the geophysical prospecting. This method mixes the sciences of geology and physics in an effort to 
help prospectors in exploring both energy fuel and mineral deposits. There are numerous examples of geophysical prospecting such as geo-magnetic surveys for looking for gold deposits, magnetic surveys for looking for iron deposits as well as the utilization of scintillation counters for sensing radioactive uranium deposits [21]. It should be noted that there are five main geophysical prospecting methods which include geo-electric, seismic, radiometric, gravimetric, and magnetic which are normally utilized in mineral exploration. Some of these techniques applications need costly and complex tools as well as sophisticated processing techniques while others have been argued to be inexpensive and relatively simple.

In gold prospecting, magnetic techniques are used since alteration gladly destroys magnetite a way that in the post-mineralization cover absence gold deposits habitually happen in the magnetic quiet zones which have been perceived to be normally numerous kilometers across [1]. This implies that the magnetic technique is particularly efficient for mapping gold ore deposits as the happen in high magnetized volcanic rocks hence making the quiet zones to be more unique. It is evident that this technique is established on mapping magnetite (magnetic materials subsurface distribution).

Magnetic gradiometry technique as well has been deemed to be a significant neat-surface geophysical prospecting method and has been largely utilized in exploration of both silver and gold deposits. This is due to the initial residue magnetic field derivative offering value-added products which might lead to the geological understanding of magnetic data [22]. Hence, the most utilized derived product is the first vertical derivative that has the formula of $\left(\mathrm{nT} \cdot \mathrm{m}^{-1}\right)$. This indicates that radiometry is a significant prospecting technique of silver and gold deposits since the adaptation of the host rocks to produce minerals like the adularia and illite imperatively increases potassium concentrates in the rock. The level of potassium incongruity is normally smaller as compared to the linked magnetic incongruity which indicates that it is more efficient at defining gold zones. This is due to adularia being inclined to be linked to the regions of maximum deposition of gold.

\section{Conclusions}

Gold prospecting has been carried out since early times. There have been numerous gold prospecting methods that have been largely used in exploration of gold. Gold prospecting methods have made a key contribution towards the exploration and discovery of new gold fields along with the extensions of subsisting gold fields. However, it has been evident that modern gold prospecting and exploration has largely been driven by technology. For instance, numerous gold and other mineral discoveries from 1950 can be attributed to geochemical and geophysical technologies that were innovated by government and industry.

Some of the modern mineral exploration technology that has assisted in the gold prospecting include; tomographic imaging, magnetic gradiometry, helicop- 
ter electromagnetic imaging, and geo-magnetic surveys. Nonetheless, in uses such technologies there is need to look at both the advantages and disadvantages of the technologies. This is due to the fact that some gold prospecting methods might be ineffective to use in certain regions or not be cost effective. Nonetheless, it can be argued that research in basic geochemical, geophysical and geological methods, along with drilling technologies might assist in improving the productivity and effectiveness of mineral prospecting. This is due to the fact that sometimes these fields overlap which indicates that development in one field is more prospectively to cross-fertilize research in other fields.

\section{Conflicts of Interest}

The authors declare no conflicts of interest regarding the publication of this paper.

\section{References}

[1] Almasi, A., Jafarirad, A., Afzal, P. and Rahimi, M. (2015) Prospecting of Gold Mineralization in Saqez Area (NW Iran) Using Geochemical, Geophysical and Geological Studies Based on Multifractal Modelling and Principal Component Analysis. Arabian Journal of Geosciences, 8, 5935-5947. https://doi.org/10.1007/s12517-014-1625-2

[2] Crowson, P.C.F. (2011) Mineral Reserves and Future Minerals Availability. Mineral Economics, 24, 1-6. https://doi.org/10.1007/s13563-011-0002-9

[3] Fletcher, W.K. (2013) Analytical Methods in Geochemical Prospecting. Volume 1, Elsevier, Amsterdam.

[4] Quick, J. and Hall, S. (2015) Part Two: Qualitative Research. Journal of Perioperative Practice, 25, 129-133. https://doi.org/10.1177/1750458915025007-803

[5] Saunders, M., Lewis, P. and Thornhill, A. (2007) Research Methods for Business Students. 4th Edition, Pearson Education Limited, New York.

[6] Veal, A.J. (2017) Research Methods for Leisure and Tourism. Pearson, London, UK.

[7] Liu, P., Luo, X., Wen, M., Zhang, J., Zheng, C., Gao, W. and Ouyang, F. (2018) Geoelectrochemical Anomaly Prospecting for Uranium Deposits in Southeastern China. Applied geochemistry, 97, 226-237. https://doi.org/10.1016/j.apgeochem.2018.07.010

[8] Eun Jung, J., Nam Kim, J. and Taek Chon, H. (2011) A Biogeochemical Orientation Survey in the Moisan Gold-Mineralized Area, Haenam District in Korea. Journal of Geochemical Exploration, 111, 152-159. https://doi.org/10.1016/j.gexplo.2011.06.005

[9] Dunn, C.E. (2007) Biogeochemistry in Mineral Exploration. Handbook of Exploration and Environmental Geochemistry, 9, 1-460. https://doi.org/10.1016/S1874-2734(07)09001-8

[10] Brooks, R.R. (1983) Biological Methods of Prospecting for Minerals. Wiley-Interscience, New York, 313.

[11] Reid, N. and Hill, S.M. (2010). Biogeochemical Sampling for Mineral Exploration in Arid Terrains: Tanami Gold Province, Australia. Journal of Geochemical Exploration, 104, 105-117. https://doi.org/10.1016/j.gexplo.2010.01.004

[12] Dunn, C.E. (1986) Biogeochemistry as an Aid to Exploration for Gold, Platinum 
and Palladium in the Northern Forests of Saskatchewan, Canada. Journal of Geochemical Exploration, 25, 21-40. https://doi.org/10.1016/0375-6742(86)90005-1

[13] Teague, J., Allen, M.J. and Scott, T.B. (2018) The Potential of Low-Cost ROV for Use in Deep-Sea Mineral, Ore Prospecting and Monitoring. Ocean Engineering, 147, 333-339. https://doi.org/10.1016/j.oceaneng.2017.10.046

[14] Mehrabi, B., Alimohamdai, H., Farhadian Babadi, M. and Ghahremani Nejad, F. (2016) Biogeochemical Exploration in Sari Gunay Gold Deposit, Northwestern Iran. Geopersia, 6, 223-232.

[15] Melchiorre, E.B., Kamenov, G.D., Sheets-Harris, C., Andronikov, A., Leatham, W.B., Yahn, J. and Lauretta, D.S. (2017) Climate-Induced Geochemical and Morphological Evolution of Placer Gold Deposits at Rich Hill, Arizona, USA. GSA Bulletin, 129, 193-202. https://doi.org/10.1130/B31522.1

[16] Makshakov, A.S. and Kravtsova, R.G. (2018) Bryolithochemical Studies in the Search for and Evaluation of Gold-Silver Mineralization Based on Stream Sediments (Northeastern Russia). Russian Geology and Geophysics, 59, 1469-1481. https://doi.org/10.1016/j.rgg.2018.10.007

[17] Rieck, R. (2017) Extended Riffle Structure for a Dry Washer. U.S. Patent No. 9802204.

[18] Chen, D., Wei, J., Wang, W., Shi, W., Li, H. and Zhan, X. (2019) Comparison of Methods for Determining the Thresholds of Geochemical Anomalies and the Prospecting Direction-A Case of Gold Deposits in the Gouli Exploration Area, Qinghai Province. Minerals, 9, 368. https://doi.org/10.3390/min9060368

[19] Sako, A., Semdé, S. and Wenmenga, U. (2018) Geochemical Evaluation of Soil, Surface Water and Groundwater Around the Tongon Gold Mining Area, Northern Cote d'Ivoire, West Africa. Journal of African Earth Sciences, 145, 297-316. https://doi.org/10.1016/j.jafrearsci.2018.05.016

[20] Yong, M., Huang, N.P. and Yu-Ming, L.Ü. (2011) Study on Soil Geochemistry and Ore Prospecting of Gold Polymetallic Deposit in Huangdanchong Area, Zhaoping, Guangxi. Gold, 32, 16-23.

[21] Yang, B., Hou, W., Liu, Z. and Meng, J. (2019) Evaluation of Deep Prospecting Methods in Hadamengou Large Gold Concentration Area, Inner Mongolia.

[22] Zhang, R.Z., Meng, Y.S. and Sai, S.X. (2016) Application of Geophysical Methods to Gold Prospecting: An Example from Loulitou District, Jiaodong Peninsula, Eastern China. 2016 International Conference on Computational Modeling, Simulation and Applied Mathematics (CMSAM 2016), Bangkok, 24-25 July 2016, 1-5. https://doi.org/10.12783/dtcse/cmsam2016/3629 